\title{
The use of ethical frameworks by students following a new science course for 16-18 year-olds
}

\author{
MICHAEL J. REISS \\ Institute of Education, University of London, 20 Bedford Way, London WC1H OAL, UK. \\ email:m.reiss@ioe.ac.uk
}

\begin{abstract}
There has been a move in recent years towards the greater inclusion of social and ethical issues within science courses. This paper examines a new context-based course for 1618 year-olds (Salters-Nuffield Advanced Biology) who are studying biology in England and Wales. The course is taught through contexts and has an emphasis on social issues and the development of ethical reasoning. Examination of a sample of reports written by students in 2005 as part of the course's summative assessment shows that utilitarian ethical reasoning is used widely and that the other ethical frameworks to which students are introduced in the course - rights and duties, autonomy and virtue ethics - are used substantially less often. In addition, students mostly argue anthropocentrically though many of them argue ecocentrically and/or biocentrically too.
\end{abstract}

In this paper I discuss the development, implementation and assessment of a way of teaching about social and ethical issues within a context-based course for 16-18 year-olds studying biology in England and Wales, focusing on the ethical frameworks used by a sample of the students on the course in some of their externally assessed examination material. The course in question (Salters-Nuffield Advanced Biology) was piloted from September 2002 and launched nationally in September 2005 as a result of approval from the national body charged with making such decisions (the Qualifications and Curriculum Authority). The course is taught through contexts and has a strong emphasis on social aspects of biology and the ethical analysis of biological issues.

\section{The principles underpinning the course}

In England and Wales, and a number of other countries with historical links to England, advanced level examinations are the examinations usually taken over two years by those students who remain in full-time education after the age of 16 years. Only about a third of students take advanced levels, which are more academically demanding that other courses on offer to this age group, and the great majority of advanced level students go on to University. 
To a certain extent, advanced level biology in England and Wales seemed during the 1990s to be in a healthier state than either advanced level chemistry or physics (Reiss, 1998). The number of candidates grew in this period and there appeared, though the data were anecdotal, to be fewer complaints in the UK from those running university biology courses about the knowledge of students coming to read undergraduate degrees in the subject compared to those running university chemistry, mathematics and physics courses.

There were, nevertheless, and still are, worrying concerns about advanced level biology, for there has been mounting (though, again, mostly anecdotal) evidence that much teaching in the subject entails little student involvement, lacks variety and is dull (Lock, 1998). Perhaps most importantly, we are now in the century that is likely to be dominated by biology and yet there has, until the project reported here, been no major curriculum initiative in the subject in England and Wales since Nuffield Biology was launched over thirty years ago. Significant and valuable work has been done by a number of groups, including the National Council for Biotechnology Education (http://www.ncbe.reading.ac.uk/) and Science and Plants for Schools (http://www-saps.plantsci.cam.ac.uk/), but even here the results have been restricted to small sections of the various specifications (syllabuses).

As a result, at least in part, of this, I would argue that the advanced level biology specifications introduced in England and Wales in September 2000 (a time when all advanced level specifications had to be revised) failed to reflect many of the tremendous advances presently being made in biology in all its diverse fields - molecular biology, cell biology, medical physiology, agriculture, genetics, biotechnology, conservation, behaviour, the brain and evolution. Furthermore, the advanced level biology textbooks and other resources that accompanied these new specifications presented a somewhat narrow impression of what it is to be a biologist, whether industrial or academic, and made disappointingly little use of recent developments in Information and Communications Technology (ICT) for teaching and learning (Hall et al., 2003). All this is at a time when there is increasing recognition that different teaching methods used in biology vary in their effectiveness (Killermann, 1996), that students learn science best by being mentally active and reflective (Woolnough et al., 1999) and that there is no substitute for student and teacher enthusiasm and engagement (Reiss, 2005).

Accordingly, on $1^{\text {st }}$ September 2000, The University of York Science Curriculum Centre and The Nuffield Curriculum Projects Centre launched the Salters-Nuffield Advanced Biology (SNAB) Project, with myself as Director. This was a major curriculum initiative to develop a new advanced level biology course. The intention was to produce a modern, relevant and exciting course that engaged students, took account of the many recent advances in biology and made use of the most appropriate teaching approaches and technologies to enable student learning. 
Much of school science has the reputation of being difficult, dull, out-of-touch with students' aspirations and irrelevant to society as a whole (Osborne et al., 2003).

Specifications have traditionally been constructed from a scientist's viewpoint with the concepts being developed in a way that is seen to be sensible by a scientist. Typically this means that preeminence is given to scientific concepts (Hart, 2002). But many students see things differently and want teachers to show them why the concepts are important. One possibility is to make the context - or storyline - the driving force. This is the approach taken with SNAB; the concepts emerge from the contexts.

A wide-ranging consultation process was undertaken to determine the overall content and form of the course. This included meetings with expert biologists, teachers, educators and students. The one-to-one discussions with academic and other specialist biologists allowed us to identify key areas of biology that were expected to make a significant contribution to the future of the subject and to society in general. One encouraging finding was the very considerable agreement among these academic and other specialist biologists as to what should be included in the course. We included these areas of biology within the course to ensure that what we produced was timely, challenging and motivated students. The choice of contexts was informed by many discussions with biologists and advanced level biology teachers. The contexts needed to be topical, of interest to the students, but also enduring. For this reason we were reluctant to have too much on recent or (then) currently newsworthy 'crises' in biology, such as BSE (bovine spongiform encephalopathy), the MMR (measles, mumps, rubella) vaccine or foot-and-mouth disease, for fear that these might date quickly. On the other hand, contexts like global climate change, genetic engineering, conservation biology, memory and cystic fibrosis are likely to be around for many years to come.

We have attempted throughout the course to make it as likely as possible that students engage with the issues, examine them critically and are able to develop their own opinions, substantiated by evidence. For instance, we use the evidence concerning global climate change as a way of allowing us to introduce the issue of what constitutes a valid scientific hypothesis and why. This should help students appreciate that there can be alternative explanations for scientific observations. We don't, for example, assume or insist that current climate change is caused by humans. Rather, we first examine the evidence that the climate really is changing; we then examine the evidence that this change is driven by human actions rather than being natural. For much the same reason we include an analysis of the way in which different websites present data on climate change to illustrate the point that scientific conclusions about controversial issues can sometimes depend on who is reaching the conclusions.

Further information about the course is available at www.advancedbiology.org and http://www.heinemann.co.uk/secondary/series/index.aspx?d=s\&skey=98 and the specification 
(syllabus) is available at

http://www.edexcel.org.uk/qualifications/QualificationAward.aspx?id=72373. What I want to do now is to discuss how and why the course deals with the teaching of ethical issues in biology. My involvement with the course from its inception means that I write not as a detached observer but as someone intimately involved in the development of the course. Although I am no longer employed on it, I remain committed to its success.

\section{Learning to analyse ethical issues in science}

Few would deny that today's biology raises a wide range of ethical issues. One only has to think of in vitro fertilisation, therapeutic cloning, genetic engineering, global climate change, conservation, animal experimentation and end-of-life issues to appreciate that. But what precisely might be the aims of teaching ethics to biology students? Based on Davis (1999), at least four can be suggested (Reiss, 1999).

First, such teaching might heighten the ethical sensitivity of participants. For example, students who have never thought about whether certain breeds of dogs should have their tails removed ('docked') or whether a fetus that is not capable of feeling anything can be said to have rights might be encouraged to think about such issues. Such thinking can result in students becoming more aware and thus more sensitive. It is not unusual, as a result, to find students saying 'I hadn't thought of that before'.

Secondly, such teaching might increase the ethical knowledge of students. The arguments in favour of this aim are much the same as the arguments in favour of teaching any knowledge - in part that such knowledge is intrinsically worth possessing, in part that possession of such knowledge has useful consequences. For example, appropriate teaching about the issue of rights might help students to distinguish between legal and moral rights, to understand something of the connections between rights and duties and to be able to identify fallacies in arguments for or against the notion of animal rights.

Thirdly, such teaching might improve the ethical judgement of students. As Davis, writing about students at university, puts it:

The course might, that is, try to increase the likelihood that students who apply what they know about ethics to a decision they recognize as ethical will get the right answer. All university courses teach judgment of one sort of another. Most find that discussing how to apply general principles helps students to apply those principles better; many also find that giving students practice in applying them helps too. Cases are an opportunity to exercise judgement. The student who has had to decide how to resolve an ethics case is better equipped to decide a case of that kind than one who has never thought about the subject. 
Fourthly, and perhaps most ambitiously, such teaching of ethics might make students better people in the sense of making them more virtuous or otherwise more likely to implement normatively right choices. For example, a unit on ethics for biology students might lead the students to reflect more on the career possibilities open to them, leading them to be less pressured by the views of others. There is, within the field of moral education, a substantial literature both on ways of teaching people to 'be good' and on evaluating how efficacious such attempts are (e.g. Wilson, 1990; Carr, 1991; Noddings, 1992). Here it suffices to note that while care needs to be taken to distinguish between moral education and moral indoctrination, there is considerable evidence that moral education programmes can achieve intended and appropriate results (e.g. Straughan, 1988; Bebeau et al., 1999).

Whether science courses should include ethical issues has been controversial (Reiss, 1999). Nevertheless, an increasing number of science courses in a number of countries do include them in part because progressive visions of scientific literacy frequently entail a commitment to the moral and ethical dimensions of science education (Zeidler, 2003). A frustration, though, that I felt as someone who taught advanced level biology and set advanced level biology papers for a decade from the mid 1980s was that in England and Wales none of the textbooks used to teach advanced level biology ever provided any sort of framework within which students could learn how to analyse ethical issues in biology. Instead, there was typically merely some sort of exhortation to teachers to include ethical aspects of biology, while students would be rewarded in their examinations merely for mentioning one or two ethical issues. Typically an essay question taking 45 minutes and worth 20 marks would have just two marks for ethical reasoning and to obtain these it would be enough simply to give one ethical argument in favour of a position and one against it - for example that growing herbicide-resistant genetically modified crops was desirable because it could reduce pesticide use but undesirable because it might lead to the evolution or more vigorous weeds.

Accordingly, the development from first principles of a new advanced level biology course, i.e. SNAB, provided the opportunity to introduce able 16-18 year-olds and their teachers to some ethical principles that would help students to analyse biological issues in real-life contexts.

SNAB is a two year course divided into eight topics (nine in the pilot version that ran from 2002 to 2005). Ethical frameworks are introduced in topic 2 in the context of a hypothetical couple, Claire and Nathan, who are deciding whether or not to have a child when they know that there is a risk that that child might have cystic fibrosis. The context of cystic fibrosis was chosen partly because of its own importance and partly because it provides an 
excellent vehicle to introduce students to monohybird inheritance, the structure of DNA, protein synthesis, cell membrane structure and functioning and ethical reasoning. The ethical frameworks introduced in the context of cystic fibrosis are reinforced in later parts of the course, for instance in the contexts of stem cell biology (is therapeutic cloning ethically acceptable?), neurophysiology (is it acceptable to use drugs in sport?) and brain studies (is it acceptable to experiment on animals as models of humans?).

There are four different ethical frameworks introduced in SNAB and the way these are introduced in the course is shown in Appendix 1. As can be seen, SNAB introduces the ethical frameworks of rights and duties, utilitarianism, autonomy and virtue ethics. Of course, trying to introduce a range of ethical frameworks in two pages of a course text for this age range and for students studying not philosophy but biology is quite a challenge. For instance, it might be argued that the material in Appendix 1 privileges autonomy. However, the principle of autonomy is widely used in medical ethics (e.g. Beauchamp \& Childress, 2001) and a number of the issues in SNAB that are analysed ethically are medical ones. In addition, autonomy has been used as an ethical principle more widely, e.g. by Ben Mepham in his widely employed 'ethical matrix' (cf. Mepham, 2005).

SNAB is therefore unashamedly pluralistic in its approach to ethics (cf. Zeidler \& Lewis, 2003). SNAB does not provide a metaethical analysis of pluralism but implicit within the course is the notion that one can be most confident about the validity and worth of an ethical conclusion if three criteria are met (Reiss, 1999). First, if the arguments that lead to the particular conclusion are convincingly supported by reason. Secondly, if the arguments are conducted within a well established ethical framework. Thirdly, if a reasonable degree of consensus exists about the validity of the conclusions, arising from a process of genuine debate.

It might be supposed that reason alone is sufficient for one to be confident about an ethical conclusion. However, there are problems in relying on reason alone when thinking ethically. In particular, there still does not exist a single universally accepted framework within which ethical questions can be decided by reason (O’Neill, 1996). Indeed, it is unlikely that such a single universally accepted framework will exist in the foreseeable future, if ever, which strongly suggests that at school level there is great worth in adopting a pluralist approach to ethics. This is not to say that reason is unnecessary but to acknowledge that reason alone is insufficient. For instance, reason cannot decide between an ethical system which looks only at the consequences of actions and one which considers whether certain actions are right or wrong in themselves, whatever their consequences. Then feminists and others have cautioned against too great an emphasis upon reason. Much of ethics still boils done to views about right and wrong informed more about what seems 'reasonable' than what follows from reasoning. 
The insufficiency of reason is a strong argument for conducting debates within wellestablished ethical frameworks, when this is possible. Traditionally, the ethical frameworks most widely accepted in most cultures arose within systems of religious belief. Nowadays, though, not everyone accepts scripture(s) as a source of authority. Another problem, of particular relevance when considering today's biology, is that while the various scriptures of the world's religions have a great deal to say about such issues as theft, killing people and sexual behaviour, they say rather less that can directly be applied to the debates that surround many of today's ethical issues, particularly those involving modern biotechnology. A further issue is that we live in an increasingly plural society. Within England and Wales, indeed, within many countries, there is no longer a single shared set of moral values. Even the various religions differ with respect to ethical matters and many people no longer accept any religious teaching.

Nevertheless, there is still great value in taking seriously the various traditions religious and otherwise - that have given rise to ethical conclusions. People do not live their lives in isolation: they grow up within particular moral traditions. Even if we end up departing somewhat from the values we received from our families and those around us as we grew up, none of us derives our moral beliefs from first principles, ex nihilo, as it were.

Given, then, the difficulties in relying solely on either reason or any one particular ethical tradition, we are forced to consider the approach of consensus (Moreno, 1995). It is true that consensus does not solve everything. Nonetheless, there are good reasons both in principle and in practice in searching for consensus. Such a consensus should be based on reason and genuine debate and take into account long established practices of ethical reasoning. At the same time, it should be open to criticism, refutation and the possibility of change. Finally, consensus should not be equated with majority voting. Consideration needs to be given to the interests of minorities, particularly if they are especially affected by the outcomes, and to those - such as young children, the mentally infirm and non-humans unable to participate in the decision-making process. Equally, it needs to be born in mind that while a consensus may eventually emerge there is an interim period when what is more important is simply to engage in valid debate in which the participants respect one another and seek for truth through dialogue (cf. Habermas, 1983; Martin, 1999).

\section{Evidence from the examinations as to how students reason ethically}

As part of SNAB, students towards the end of the first year of their course (when they are nearly all either 16 or 17 years in age) have to submit a report approximately 1500 words in length of a biological issue or of a biological visit that they have made. These reports are marked externally (i.e. by examiners external to each student's school rather than by a teacher 
within their school). The criteria on which the reports are marked are published and made available to students and their teachers. These criteria include the statement that "They should demonstrate an understanding of the ethical, social, economic and environmental implications of the applications of biology encountered within the context of the visit or issue" (Edexcel, 2002, page 27).

At my request, an administrator at Edexcel (the Awarding Body responsible for assessing the course) identified those visit / issue reports submitted in 2005 that she felt were to do with global warming. I chose the topic of global warming since, while students write their reports on a tremendous range of topics, I was keen to conduct the analysis on reports that identified just one aspect of biology and the principal examiner for the reports had identified that there were more reports on this topic than on any other. (Students were free to choose the titles of their reports and while some titles of reports analysed here stipulated global warming, e.g. 'Can energy crops slow the rate of global warming?' and 'Is the rate of global warming increasing and what will be the consequences of such happenings in the future?', not all did, e.g. 'A visit to the Natural History Museum'.) In all, the administrator at Edexcel identified a total of 18 reports that were to do with global warming. One of these could not be analysed owing to problems with scanning.

These 17 visit/issue reports were carefully read and coded by me according to the ethical framework(s) that each report used. There were four possible frameworks:

- Rights and duties

- Utilitarianism

- Autonomy

- Virtue ethics.

Any one report could, in principle, use none, one, two, three or four of these frameworks. As one typically finds when coding responses, some were easy to code, others more difficult. For example there is a suggestion that the bullet point:

Conflicts between farmers using pesticides to protect their livelihood and environmentalists who see the further damage to the environment that increasing use of these pesticides create.

(Student 15, page 9)

might sit within a rights and duties framework. However, the mere mention of 'Conflicts' was deemed insufficient to conclude this with any confidence. An instance where a response was coded as 'rights \& duties' is provided by: 
(Student 13, page 4)

An example of a response being coded as 'autonomy' is:

We all have a right to choose for ourselves whether we use fossil fuels to achieve a good standard of living

(Student 13, page 4)

though this response illustrates the fact that autonomy really sits within rights and duties.

An example of a response being coded as 'utilitarianism' is:

In conclusion, as temperatures rise across the globe, migration patterns will change for all animals. It will mean that new species, which would not have previously been able to survive in the UK's temperature, will be able to live perfectly well here. It will also mean that species that migrate south during the winter months due to the cold weather in the UK, now wont have to. They will be able to stay all year round. This could mean huge changes in the eco-system. It could cause the destruction of thousand of crops if new pests entered the country that farmers were not prepared for, it could cause the destruction of many more trees and plants for food for these new animals, and it could cause problems for humans as well, if for example, rabbis or malaria came to the UK because of these hotter climates.

(Student 16, page 5)

An example (actually, the only example) of a response being coded as virtue ethics was the following:

The Kyoto Protocol opened for signature on December 11, 1997 in Kyoto, Japan. It was entered into force on February 16, 2005. As of April 2006, 163 countries have signed the agreement. However, American didn't agree to cut down their emissions of fossil fuel under the Bush administration because many of their big companies were heavily reliant on all fuels and they say that this would have grave consequences for the U.S. economy, and because they state that there is no scientific evidence to back up global warming. They would rather help out themselves and be selfish rather than the rest of the world which is bad ethics.

(Student 4, page 4)

Of the 17 reports, 16 used a utilitarian framework, four used a framework of rights and duties, three a framework of autonomy, and one used a framework of virtue. Two of the reports used three frameworks (rights and duties, utilitarianism and autonomy in both cases), three used two frameworks (rights and duties and autonomy in one case, rights and duties and 
utilitarianism in the second case, and utilitarianism and virtue ethics in the third case) and the other 12 used a single framework (utilitarianism in all cases).

One reason for the predominance of the utilitarian framework is that almost any argument that talked about the (possible) consequences of climate change without using technical ethical terms was likely to be classified as utilitarianism although a stricter classification might have classified such responses as consequentialist. An example of such an argument is as follows:

Some insects that come each summer at the moment are wiped out by winter time due to the freezing temperatures. These insects are dangerous to the English habitats as they can destroy trees, grasses and other indigenous plants and therefore their habitat. They can also destron the agriculture with significant effects. An example of this is the Silver Y Moth (pictured below) [photograph omitted by M. Reiss].

It comes to the UK most years and ruins sugar beat crops. This has economic effects on farmers as they have less sugar beet to harvest and therefore less to sell resulting in a lower income. But up to now the effects have been relatively small most years as the moths are in small numbers and don't survive the winter. If these pests can survive the winter then they will be able to gain large numbers and do significant damage. The obvious economic effects are that farmers will not get an acceptable yield therefore decreasing their income each year and many farms will have to shut down. Also the insects will interrupt the natural ecosystems replacing many of the existing insects and other primary consumers (herbivores).

(Student 8, pages 1-2)

This quote also illustrates the way in which a quite different ethical analysis could have been undertaken - for instance on the extent to which arguments were anthropocentric, biocentric or ecocentric and, if biocentric, privileged sentient organisms. Similarly, the following quote exemplifies how there were occasional references to international development issues:

The effects of switching to more eco-friendly processes could result in the prevention of global warming and climate change, and to the salvation of many habitats and species, without too much of an intrusion into our own lifestyles. The demand for eco-friendly products would also mean that many less economically developed countries would be able to export useful plants such as hemp to other countries which use/produce the products, In turn this could result in these countries being able to develop to stages where cleaner industry would replace the dirty industry which many of them rely on today for their current economies. 
Accordingly, the 17 reports were re-read to see the extent to which students employed anthropocentric arguments (i.e. those that rest on the consequences to / interests of humans), biocentric arguments (those that relate to animals, particularly animals capable of feeling pleasures and pains) or ecocentric arguments (those that relate to ecosystems or other groupings that include non-sentient organisms such as plants or corals). This is, at least in theory, a straightforward way of categorising positions in the environmental ethics field (cf. Attfield, 1998). I say 'at least in theory' because many of the students who authored the 17 reports conflated these arguments. For example, one student wrote:

In each case life will become much harsher with a massive reduction in the Earth's population, both human and animal, as a result of ecosystems failing due to lack of food for sustenance, and extreme weather conditions which could alter too fast for animal and plant species to evolve to cope with them.

(Student 7, pages 1-2)

In a single sentence, this student employs all three arguments. Another example is provided by the following quote:

The change in the climate is giving rise to new crops growing in this country which would have previously been unable to thrive before such as elephant grass, Japanese knot weed as well as other "water weeds". The Japanese weed is particularly a problem as not only is it hard to kill, but in the ground as it has deep roots and it can even grow up through buildings which causes huge problems as it throws its structural strength in to uncertainty as it can and usually does weakens the structure of the building. The "water weeds" like Lilly pads can cause a huge threat to animals and children as the weeds will reach a state where they will completely cover the ground and cause it to look just like solid ground. The threat this poses is that the children and animals could run right into these weeds without knowing the water is there get into real danger and possibly drown. Another effect of these weeds is that the will kill off any other life in the water itself, the plants at the bottom will have their sunlight blocked and be unable to perform photosynthesis and, therefore, cannot add more $\mathrm{O}_{2}$ and as such they simply choke themselves to death. This also effects the fish and any other insects that live in the water as the $\mathrm{O}_{2}$ is removed from the water and none is replaced and they eventually suffocate.

(Student 12, page 2)

For this reason, and because I feel interviewing would be needed more carefully to tease apart the underlying reasons for their positions, I am reluctant to read too much into any quantitative analysis of the extent to which the 17 students employed anthropocentric, biocentric or ecocentric arguments. Nevertheless, my analysis suggests that most students 
employed anthropocentric, biocentric and ecocentric arguments; in all 16 of the 17 students used anthropocentric arguments, 14 used ecocentric ones and 13 used biocentric ones. It must be emphasised, though, that almost invariably more time was spent by each student on anthropocentric considerations than on biocentric or ecocentric ones. Even one student who spent almost a third of their report writing about the effects of climate change on butterflies suddenly included anthropocentric considerations by reasoning:

The changes in migration and habitat patterns of these butterflies could have great effects of the eco-system in this country. Butterflies suck the sap from trees and plants as a source of energy. If the amount of butterflies around increased dramatically, this could cause the trees and plants they use of feed off to die out, cases problems for farmers, if it is their crop that the butterflies are killing, and also destroying the habitat of other animals.

(Student 16, page 4)

\section{Discussion}

Salters-Nuffield Advanced Biology concentrates on the second and third of the possible aims identified by Davis (1999) and Reiss (1999) when teaching about ethics, namely increasing the ethical knowledge and the judgement of students. Furthermore, it is likely that the aim of increasing the ethical sensitivity of students correlates to some extent with these two aims, and it may be that some students do indeed become morally better people as a result of studying the course, though this is not an expressed aim.

The analysis of the 17 student reports presented here should not, of course, be taken as being representative. Indeed, they are clearly not independent. While data on the school from which each student came was not available to me, fully 12 of the 17 analysed reports were of visits to the Central Science Laboratories, Sand Hutton, York. The other five consisted of three issue reports, one report of a visit to the Natural History Museum and one report of a visit to the Institute of Arable Crop Research at Rothamsted.

Notwithstanding this, a number of conclusions can tentatively be drawn. First, ethical reasoning was widely employed - indeed by all 17 students whose work was analysed. Furthermore, it should be noted that ethical reasoning was only one of many criteria that reports had to satisfy to score well. In other words, these assignments were not ethics assignments. They were science (advanced level biology) assignments where one of the criteria was that they should demonstrate an understanding of the ethical, social, economic and environmental implications of the applications of biology encountered within the context of the visit or issue. 
Secondly, the students were able validly to reason about ethical matters. This is a considerable achievement on the part of the students. Whilst a reader might, of course, question the way in which, for example, students weighed alternative ethical concerns, nevertheless, there is considerable and sustained evidence of students adducing evidence and arguing coherently about ethical matters.

Thirdly, there is a marked preference among students for utilitarian reasoning to be employed. Of the 17 reports, 16 used utilitarian reasoning, four employed a framework of rights and duties, three a framework of autonomy and only one utilised virtue ethics, though one other did briefly discuss whether "it may be too late to prevent global warming" or whether "there is still hope" of so doing (Student 7, page 4). A number of reasons can be suggested for this apparent preference for utilitarianism. For one thing, the nature of the topic, global warming, may be one that encourages students to weigh up the pros and cons and this is likely to result in a consequentialist approach being taken. It is possible that, for example, that had I analysed reports about the use of animals in medical experiments, rights and duties would have featured more strongly. Further research could address such questions.

Fourthly, most students employed anthropocentric arguments, though biocentric and ecocentric arguments were frequent too. It seems virtually certain that the extent to which students employ anthropocentric, biocentric or ecocentric reasoning depends at least in part on the issue at hand (e.g. global warming lends itself to ecocentric viewpoints in a way that arguments about embryonic stem cells do not). Again, further research could address this question.

A final point is that both science students and their teachers need support if they are to learn to reason ethically. The majority of the 100 or so teachers involved in teaching the SNAB pilot (to a total of about 5000 students over three years) attended an interactive session on teaching ethics that I ran and which lasted about one and a half hours (and typically had about 20 teachers present) as part of a two and a half day residential course that we ran before most teachers started teaching the course. As the course has gone national (from September 2005) increasing numbers make this difficult for all new teachers. Instead, to supplement continued face-to-face sessions, we have put together a pack of materials for teachers to use in continuing professional development sessions. One of these sessions looks at the teaching of ethical issues. It remains to be seen how successful this is but there is an encouraging growth in the UK in the teaching of ethical aspects of biology and I am hopeful that the movement is increasingly self-sustaining.

\section{References}


Attfield, R.: 1998, 'Environmental ethics, overview'. In: R. Chadwick (ed.)

Encyclopedia of Applied Ethics, Volume 2, E-I, Academic Press, San Diego, pp.73-81.

Beauchamp, T.L. \& Childress, J.F.: 2001, Principles of Biomedical Ethics, $5^{\text {th }}$ edn, Oxford University Press, Oxford.

Bebeau, M.J., Rest, J.R. \& Narvaez, D.: 1999, 'Beyond the promise: a perspective on research in moral education', Educational Researcher 28(4), 18-26.

Carr, D.: 1991, Educating the Virtues: An Essay on the Philosophical Psychology of Moral Development and Education, Routledge, London.

Davis, M.: 1999, Ethics and the University, Routledge, London.

Edexcel: 2002, Edexcel Advanced Subsidiary GCE in Biology (Salters-Nuffield) (Pilot) 8048 and Advanced GCE in Biology (Salters-Nuffield) (Pilot) 9048, Edexcel, London.

Habermas, J.: 1983, Moralbewusstsein und Kommunikatives Handeln, Suhrkamp Verlag, Frankfurt am Main.

Hall, A., Reiss, M. \& Scott, A. (eds): 2002, Salters-Nuffield Advanced Biology AS Student Book 1, Pilot edition, Heinemann, Oxford.

Hall, A., Reiss, M.J., Rowell C. \& Scott, C.: 2003, 'Designing and implementing a new advanced level biology course', Journal of Biological Education 37, 161-167.

Hart, C.: 2002, 'Framing curriculum discursively: theoretical perspectives on the experience of VCE Physics', International Journal of Science Education 24, 10551077.

Killermann, W.: 1996, 'Biology education in Germany: research into the effectiveness of different teaching methods', International Journal of Science Education 18, 333346.

Lock, R.: 1998, 'Advanced-level biology - is there a problem', School Science Review 80 (290), 25-28. 
Martin, P.A.: 1999, 'Bioethics and the whole: pluralism, consensus, and the transmutation of bioethical methods into gold', Journal of Law, Medicine \& Ethics 27, 316-327.

Mepham, B.: 2005, Bioethics: An Introduction for the Biosciences, Oxford University Press, Oxford.

Moreno, J.D.: 1995, Deciding Together: Bioethics and Moral Consensus, Oxford University Press, Oxford.

Noddings, N.: 1992, The Challenge to Schools: An Alternative Approach to Education, Teachers College Press, New York.

O’Neill, O.: 1996. Towards Justice and Virtue: A Constructive Account of Practical Reasoning, Cambridge University Press, Cambridge.

Osborne, J., Simon, S. \& Collins, S.: 2003, 'Attitudes towards science: a review of the literature and its implications', International Journal of Science Education 25, 10491079 .

Reiss, M.J.: 1998, 'The future of life science education', School Science Review 79(289), 19-24.

Reiss, M.J.: 1999, ‘Teaching ethics in science', Studies in Science Education 34, 115140.

Reiss, M.J.: 2005, 'The importance of affect in science education'. In: S. Alsop (ed.) Beyond Cartesian Dualism: Encountering Affect in the Teaching and Learning of Science, Kluwer, Dordrecht, pp.17-25.

Straughan, R.: 1988, Can We Teach Children to be Good? Basic Issues in Moral, Personal and Social Education, 2nd edn, Open University Press, Milton Keynes.

Wilson, J.: 1990, A New Introduction to Moral Education, Cassell, London. 
Woolnough, B.E., McLaughlin, S. \& Jackson, S.: 1999, 'Learning by doing - two classroom studies of pupils' preferred ways of learning science', School Science Review 81(294), 27-34.

Zeidler, D.L.: (ed.) 2003, The Role of Moral Reasoning on Socioscientific Issues and Discourse in Science Education, Kluwer, Dordrecht.

Zeidler, D.L. \& Lewis, J.: 2003, 'Unifying themes in moral reasoning on socioscientific issues and discourse'. In D.L. Zeidler (ed.) The Role of Moral Reasoning on Socioscientific Issues and Discourse in Science Education, Kluwer, Dordrecht, pp.289-295. 


\section{Appendix 1 The ethical frameworks introduced in Salters-Nuffield Advanced Biology}

(Hall et al., 2002, pp. 93-94). (Terms in bold are defined in the course glossary.)

\section{What is right and what is wrong?}

How should we decide in life what is right and what is wrong? For example, should we always tell the truth? Can we ever justify turning down a request for help? Should Claire and Nathan have an abortion if they find that their unborn baby has cystic fibrosis?

All of us have moral views about these and other matters. For example, you might hold that lying and abortion are always wrong and helping people always right. But in order to maintain that something is ethically acceptable or unacceptable, you must be able to provide a reasonable explanation as to why that is the case.

There is no one universally accepted way of deciding whether something is ethically acceptable or not. What there are instead are a number of ethical frameworks each of which allows you to work out whether a particular action would be right or wrong if you accept the ethical principles on which the framework is based. Usually you get the same answer whichever framework you adopt. But not always! This is why perfectly thoughtful, kind and intelligent people sometimes still disagree completely about whether a particular course of action is justified or not.

We will examine four widely used ethical frameworks. You should find these of value when considering various issues, such as genetic screening and abortion, raised in this topic. We will also refer to these frameworks in other topics in this course.

\section{Rights and duties}

Most of us tend to feel that there are certain human rights that should always be permitted. For example, we talk about the right to life, the right to a fair trial and the right to freedom of speech. Certain countries, for example the USA, have some of these rights enshrined in their constitutions.

If you have a right to something, then I may have particular duties towards you. For example, suppose that you are a six month old baby with a right to life and I am your parent. I have a duty to feed you, wash you, keep you warm and so on. If I don't fulfil these duties, I am failing to carry out my responsibilities and the police or social services may intervene. 
But where do rights come from? Some people with a religious faith find them in the teachings of their religion. For example the ten commandments in the Jewish scriptures talk about not stealing, not murdering, telling the truth and so on.

But nowadays, of course, many people, indeed in the UK most people, have little or no religious faith. So where can they - perhaps you - find rights? The simplest answer is that rights are social conventions built up over thousands of years. If you want to live in a society you have, more or less, to abide by its conventions.

\section{Maximising the amount of good in the world}

Perhaps the simplest ethical framework says that each of us should do whatever maximises the amount of good in the world. For example, should I tell the truth? Usually yes, as telling lies often ends up making people unhappy and unhappiness is not a good. But sometimes telling the truth can lead to more unhappiness. If your friend asks you if you like the present they have just given you and you don't, would you tell the truth? Most of us would tell a 'white lie', not wanting to harm their feelings.

This ethical approach is known as utilitarianism. Notice that utilitarians have no moral absolutes. A utilitarian would hesitate to state that anything is always right or always wrong. There might be circumstances in which something normally right (e.g. keeping a promise) would be wrong and there might be circumstances when something normally wrong (e.g. killing someone) would be right.

\section{Making decisions for yourself}

One of the key things about being a human is that we can make our own decisions. There was, for example, a time when doctors simply told their patients what was best for them. Now, though, there has been a strong move towards enabling patients to act autonomously. People act autonomously when they make up their own mind about something. If you have ever had an operation, you will probably have signed a consent form. The thinking behind this is that it isn't good for a surgeon to be allowed to operate on you unless you have given informed consent.

Of course, it is perfectly possible autonomously to decide to be absolutely selfish! Autonomy clearly isn't the only good in the world. A utilitarian would say we need to weigh the benefits 
of someone acting autonomously with any costs of them doing so. Only if the overall benefits are greater than the overall costs is autonomy desirable. Someone who believes in rights and duties might say that each of us has a right to act autonomously but also has a duty to take account of the effects of our actions on others.

\section{Leading a virtuous life}

A final approach is one of the oldest. This holds that the good life (in every sense of the term) consists of acting virtuously. This may sound rather old-fashioned but consider the virtues that you might wish a good teacher/lecturer to have. She or he might be understanding, able to get you to learn what you want/need to learn and believe in treating students fairly.

Traditionally the seven virtues were said to be justice, prudence (i.e. wisdom), temperance (i.e. acting in moderation), fortitude (i.e. courage), faith, hope and charity. Precisely what leading a virtuous life means can vary. Think about the virtues you might like to see in a parent, a doctor and a girl- / boyfriend. What would be the virtuous course of action for Claire and Nathan? 